\title{
Ranching on the Right Side of History
}

\section{By Tom Isern}

$\mathrm{I}$ ke Blasingame had a good horse, a blood-bay gelding he called C Heart, under him that warm spring day of 1905 as he approached the east bank of the Missouri River. He considered the proposition of crossing the ice to get back to Matador headquarters on the west side, in the grazing lease on the Cheyenne River Reservation. The horse was shy of the honeycombed ice with pools of water on the surface, but Ike had liquored up in the cattle-shipping town of Evarts, and he spurred his mount across. He had stayed too long in town; he should have been back on the job. As things turned out, he was lucky he made it at all. The hardy horse clambered out of trouble again and again, at one point pulling himself out from a hip-deep immersion. "Both of us were thankful to get off that river," recalled Ike, no stranger to dangerous scrapes. "By sundown, the ice burst apart, booming like a cannon as it split in a thousand directions."

Range memoirs, such as Ike Blasingame's Dakota Cowboy, ${ }^{1}$ are filled with hair's-breadth escapes from deadly peril and with second-guessing of decisions made at the time. Reading the broader history of the range cattle industry during its heyday on the northern plains likewise offers opportunity for second-guessing with benefit of hindsightalways a dubious undertaking. Nevertheless, the chronicle fairly shouts a catalog of lessons for riders of the northern range in any generation of the livestock industry. The biggest lesson is this: do not let yourself get situated on the wrong side of things, like Ike did that day in 1905. The record of the livestock industry as to staying on the right side of history is checkered at best. Too often stockmen have been swamped by developments they ought to have foreseen and navigated.

The first problem in learning from the early experience of ranching on the northern plains is to overcome collective memory. Over time we, professional historians and the public together, have fashioned a grand narrative, a certain way of telling the story of the range, that does not necessarily reflect what happened on the ground. Our grand narrative goes like this.

The North American range cattle industry began in south Texas, being Hispanic in origin - its methods of handling cattle, its genetics both bovine and equine, and its very extensive nature. The Hispanic system of ranching, once co-opted by Anglos, became the Texas system. Following the Civil War the Texas system dispersed north with the long drive, whereby southern cattle were delivered to shipping points in Kansas and Nebraska. Longhorns not shipped east to packers or feeders were wintered or, once Indian conflicts had wound down, driven on north to mature and fatten as well as to establish breeding herds. These rangers, as the Texas longhorns were called, were the stock and trade of the Cattle Kingdom of the 1870s and 1880s.

The Cattle Kingdom of Wyoming, Montana, and Dakota reached its pinnacle in the early 1880s. Prompted by such enthusiastic tracts as Cattle-Raising on the Plains of North America $(1885)^{2}$ by Walter Baron von Richthofen (uncle and godfather to the Red Baron, World War I flying ace), eastern and foreign investors poured capital into the cattle industry. The northern range became seriously overstocked.

Then came the hard winter of 1886-1887. Following a droughty summer, cattle entered the winter in poor shape and with forage depleted. Winter arrived early, the blizzards came one after another, and temperatures were 40 below

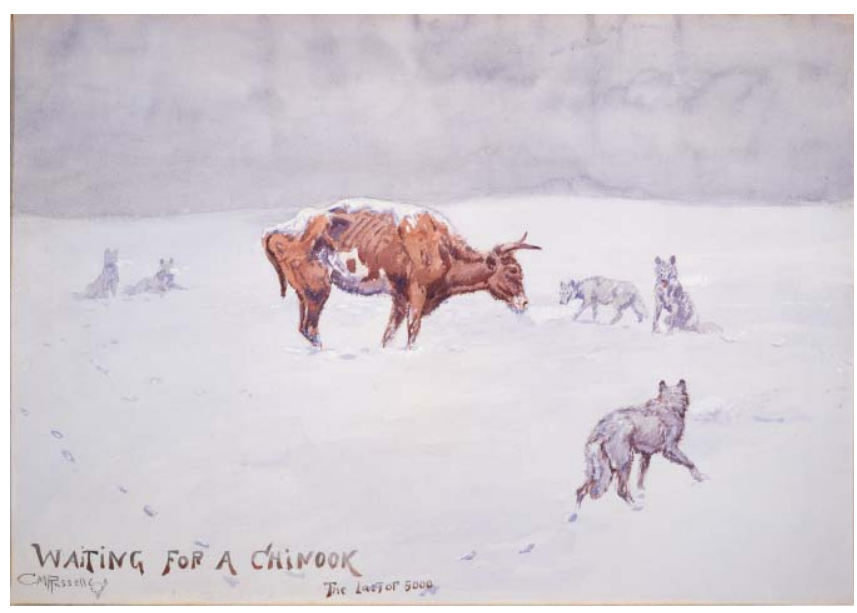

Postcard versions of Waiting for a Chinook, by cowboy artist Charley Russell, circulated widely. Photo courtesy of Buffalo Bill Historical Center, Cody, Wyoming, USA; gift of Charles Ulrick and Josephine Bay Foundation, Inc. 


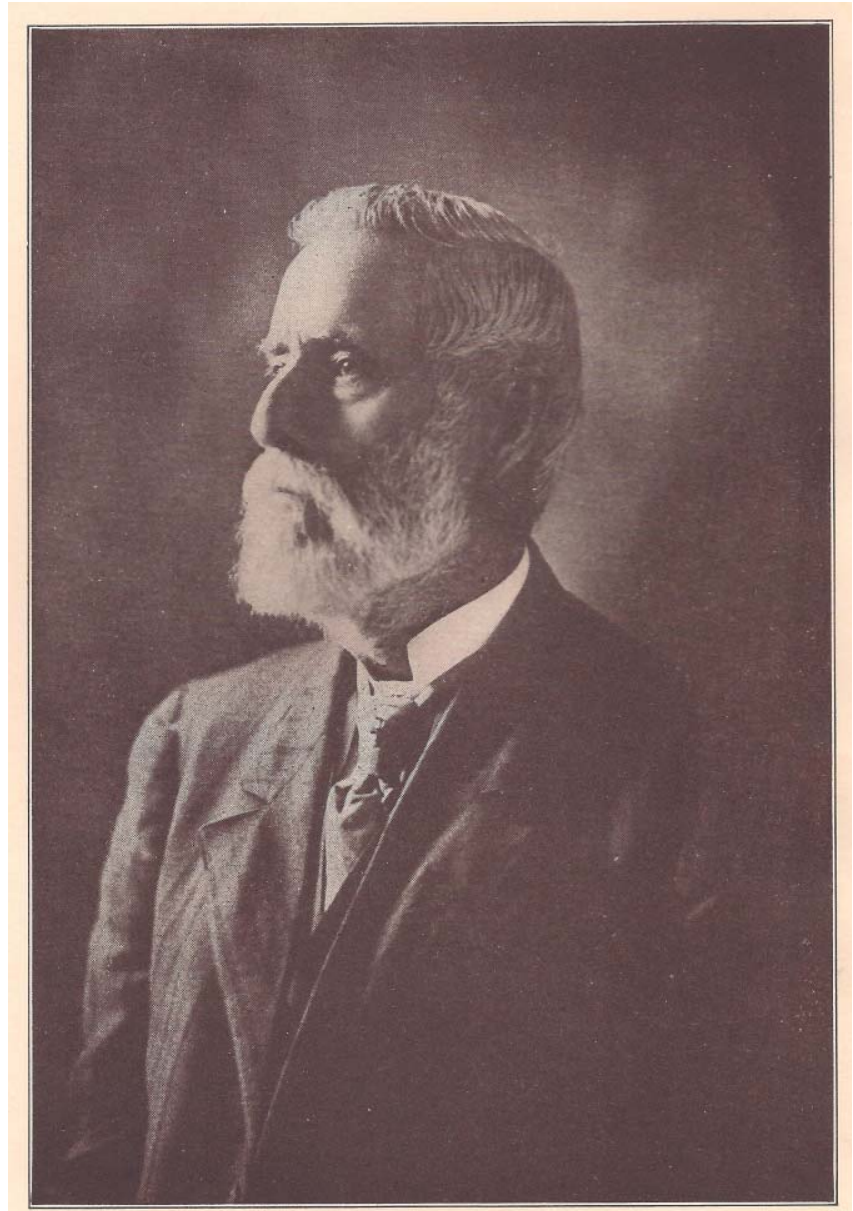

Granville Stuart, aged 75

Memoirists such as Granville Stuart, the Montana cattleman, shaped the grand narrative of the range cattle industry.

and worse. Chinooks came, but they served only to melt the surface of the snow, after which it froze hard, preventing even the best rustlers among the starving cattle from pawing through. Cowboys just let the herds go. Come spring, they and their employers commonly estimated losses at 90 percent. Cowboy artist Charlie Russell illustrated the disastrous situation with his famous watercolor Waiting for a Chinook.

The Blue Winter of 1886-1887 changed everything. As the founding father of the Montana range cattle industry, Granville Stuart, wrote in his memoirs, "A business that had been fascinating to me before, suddenly became distasteful. I wanted no more of it. I never wanted to own again an animal that I could not feed and shelter."

As the big operators like Stuart quit the range, smaller, family enterprises got their chance. They put up hay for winter feed, fenced the range, bred up their herds with Hereford and Angus sires, and in general, took care of their cattle. Thus out of the crisis of the 1880s emerged the modern ranching industry.

We feel pretty good about this story because it leaves responsible, family-oriented folk at home on the range

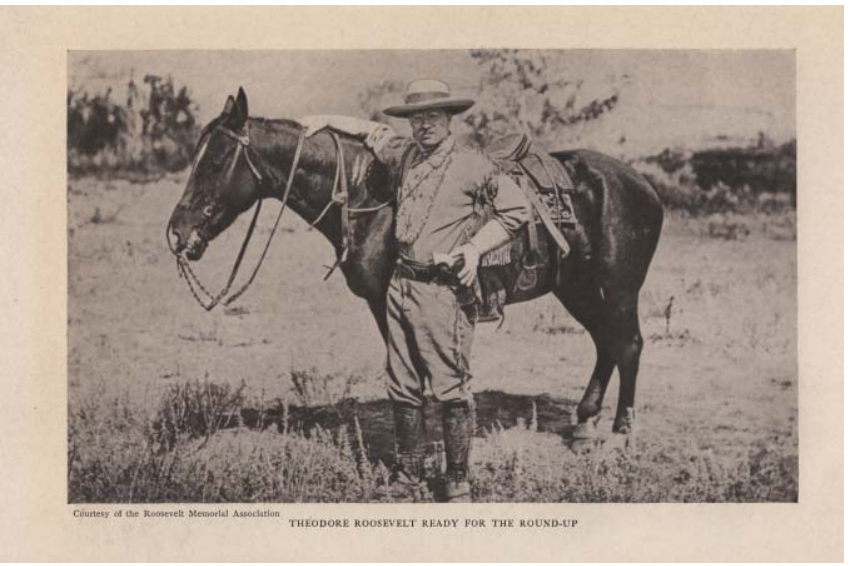

Lincoln Lang published this image of "Theodore Roosevelt Ready for the Round-Up" in his badlands ranching memoir Ranching with Roosevelt. ${ }^{5}$

exercising husbandry. It situates us for the present. It gives us a pantheon of larger-than-life heroes, such as Stuart, Boss Cowman Ed Lemmon, and Teddy Roosevelt, who said his ranch experiences in the Badlands made him the man he was. It leaves us a legacy of great stories in books such as Blasingame's or Teddy Blue Abbott's We Pointed Them North. ${ }^{4}$ As soon as you pull a thread out of the grand narrative of ranching, though, it starts to unravel.

In the first place, there is the tendency of the old story to carry too much moral freight. Taking cues from the writings of Stuart, for instance, or those of one of Roosevelt's neighbors, Lincoln Lang, ranchers and ranch historians claim moral high ground. They knew the range was overstocked, they allow; people behaved badly during the 1880s, and the hard winter of $1886-1887$ was a judgment upon them, from which they learned important lessons. The problem is, all this prescience shows up in remembrances written many years later-as with Lang in his memoir, Ranching with Roosevelt. "The White Man had desecrated Nature's preserves," Lang intones. "Nature had come back at him in full measure and had retaliated in her own peculiar way." He published these remarks, imbued with the conservation ethic of his presidential hero, in 1926.

Some irreverent historians have suggested that the Blue Winter actually saved some stockmen from financial ruin. They were able to claim winter losses of literally unnumbered cattle that had existed previously not by visual confirmation but only in "book count," as the phrase of the time went. It is clear from the record, too, that the big outfits were not wiped out by the catastrophic winter; rather, they merely continued an ongoing process of orderly liquidation inspired by depressed markets for beef.

Then consider the findings of grassland historian Geoff Cunfer in On the Great Plains. ${ }^{6}$ Cunfer studies population levels of bison in the era preceding ranching, totals numbers of cattle reported on range in the 1880s, and considers the data in the light of more recent knowledge of stocking 
practices and carrying capacity. He concludes that the northern ranges, except perhaps in local cases, could not possibly have been, by any reasonable definition, overstocked during the 1880s. As a current scholar of the Musselshell range of Montana (M. D. Lewis, dissertation in progress at North Dakota State University), observes, "What happened was not a failure to take care of the range, it was a failure to take care of cattle."

The ecological morality tale of the 1880s is blended with a sanguine story of the transition from open range to modern ranching. How did this happen? Collective memory admits there might have been some early operators on the open range who got on the wrong side of history and terrorized their rivals - be they upstart small operators, homesteading farmers, or, perish the thought, sheepmen. This served, though, only to generate a new crop of culture heroes who, like Alan Ladd as Shane or Jules Sandoz in his daughter's remembrances of the sandhills, fought to restore justice and opportunity for all. ${ }^{7}$ Mostly, we are given to believe, things transitioned amicably. Stuart recalls that he let his homesteading neighbors milk his range cows, and then helped them out by buying the butter they made from his own cream.

Stuart also, however, was the leader of Stuart's Stranglers, the band of cattleman vigilantes who in 1884 set out to rid the country around the mouth of the Musselshell of rustlers by burning them out and stringing them up. They gave the same murderous treatment to Indians found off reservation and, presumably, killing cattle. "The men that were taken were members of an organized band of thieves that for more than two years had evaded the law and robbed the range at will," Stuart writes. Furthermore, "there never was any trouble between the cattle and sheep men of Montana."

Some shepherds would disagree. Moreover, there is room for doubt about ranchers' complaints of rustlers and about their justification of lynch law. The most infamous instance of such developments was the Johnson County War of 1892. In this case prominent members of the Wyoming Stock Growers Association, accompanied by a gang of hired guns, invaded Johnson County, Wyoming, with the announced intention of killing rustlers. After a couple of killings, however, a posse of local citizens attacked and besieged the invaders until federal troops arrived to take the ranchers and gunmen into custody.

This episode is the subject of a new book called Wyoming Range War, by John W. Davis, attorney and historian. ${ }^{8}$ His close study of legal records and newspaper reports finds that contrary to the big cattlemen's claims, there was no epidemic of rustling in Johnson County. Local law enforcement was functioning rather well. He concludes that the aim of the Johnson County invaders was not so much to eradicate rustlers as to eliminate rivals, mainly small-time cattlemen, for use of the range. The big stockmen tried to suppress the facts about the situation in Johnson County and get their own story of self-justification before the public,

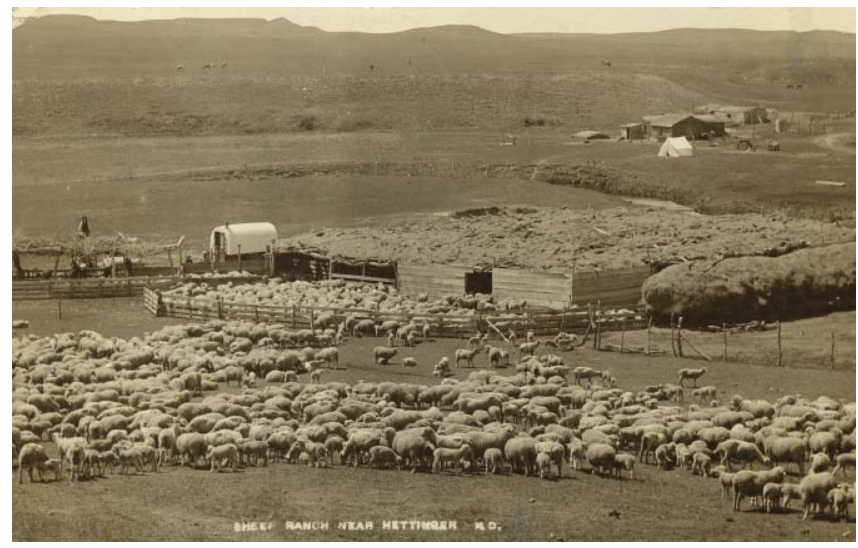

Sheep ranch near Hettinger, North Dakota, around 1900, heyday of sheep culture on the northern range. Photo courtesy of Institute for Regional Studies, North Dakota State University.

but public relations could not salvage a way of life at odds with public values and the law.

The role of sheep culture in this not-so-orderly transition is commonly ignored, but a close reading even of such classic accounts of the range cattle industry as Ernest Osgood's Day of the Cattleman discloses that the immediate successor to the Longhorn on the northern ranges was not the Hereford, but the Merino. ${ }^{9}$ Flocks were trailed across from California and Oregon to fill the range from which cattlemen were withdrawing, a story told in Edward Norris Wentworth's pioneering history America's Sheep Trails. ${ }^{10}$ Not until well into the twentieth century would cattle culture, in the style of modern ranching, again predominate over sheep culture on the northern plains. One watermark of the heyday of sheep on the range is the cultured and witty memoir Sheep by Archer Gilfillan. ${ }^{11}$

Thus the transition from the open range to modern cattle ranching stretches from the late 1880s to the early 1920s. The science of range management, largely based on the invention of grassland ecology at the University of Nebraska in the 1890s, dates from just about the time that the transition to modern cattle ranching was completed. Scientific range management and modern cattle ranching were contemporary developments and have waltzed with one another, and told one another's stories, ever since their origins.

Cattle ranching and range management in the twentyfirst century can profit from attention both to the grand narrative of cattle ranching on the northern plains and to its revisionary addenda. The grand narrative gives us a mythology full of heroes and symbols - an identity, in other words. The revised story gives us a sounder basis for assessing our situation and considering courses of action.

This begins with a recognition of possibilities-what historians call "contingency." It is clear from the evidence that the modern ranching industry was not ordained by God or environment or economics to establish and maintain itself on the northern plains. There have been other ways of living 


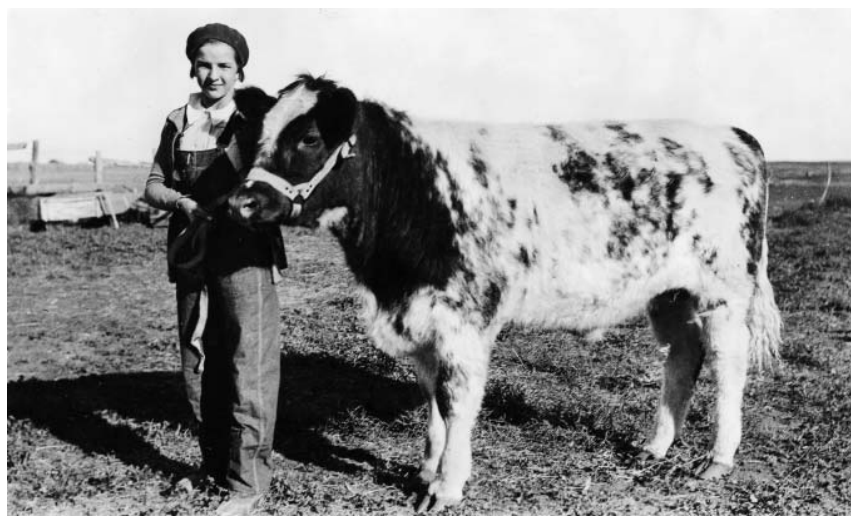

Modern ranching changing with the times: Arlene Rothi gender-integrates the Pursian Park Baby Beef Club, 1936, Kidder County, North Dakota. Photo courtesy North Dakota State University Archives.

and operating and using the land before, and might well be others in future. Maintenance of cattle ranching as an industry and as a way of life is not a historical entitlement. It is something that has to be husbanded and maintainedin a fashion better, we may hope, than did the open-range stockmen of the past.

Such husbandry has to take into account changes in the land, changing environmental conditions. Contrary to the beliefs of both the open range stockmen and the early grassland ecologists, the grasslands of the northern plains are neither static nor cyclical. The state of nature is not stability, but transition. One of the ironic lessons of history is that management requires sensitivity to changes that cannot be projected from past patterns, because they have no known precedent. Prescience in hindsight, like that of Granville Stuart, is of little use. Watchful sensitivity to changes in the land is better.

Evolving relationships with the land take place in the context of changes in society and its cultural values. The open range cattlemen got themselves on the wrong side of history, of Alan Ladd, and of powerful American values that insisted on public access to public lands. In conflicts with societal values, energetic public relations cannot dissipate fundamental disagreements. Real changes in public values require real changes on the western range.

Finally, if there is a constant in the trajectory of ranching on the northern plains since the 1870s, it is in the direction of greater and better husbandry. Sheep culture succeeded open range cattle culture because shepherds took care of their animals. Modern cattle ranching was able to reassert cattle culture only by practicing comparable animal husbandry, along with availing itself of better genetics. Range management extended the practice of husbandry also to the land and grass. If history is any guide-if, as the cowboy historian E. E. Dale said, "the lamp of experience has ever furnished the chief light by which our feet are guided"then the answers to multiple challenges facing ranching and range management in the twenty-first century hinge on the redefinition and elaboration of the historic virtues of husbandry. ${ }^{12}$

\section{References}

1. Blasingame, I. 1958. Dakota cowboy: my life in the old days. New York, NY, USA: Putnam's Sons. 317 p.

2. Richthofen, W. 1885. Cattle-raising on the plains of North America. New York, NY, USA: D. Appleton \& Co. 112 p.

3. StUART, G. 1925. Forty years on the frontier. 2 vols. Cleveland, OH, USA: Arthur H. Clark. $272+265$ p.

4. Аввотт, Е. С. 1939. We pointed them north, recollections of a cowpuncher. New York, NY, USA: Farrar \& Rinehart. 247 p.

5. LANG, L. 1926. Ranching with Roosevelt. Philadelphia, PA, USA: J. B. Lippincott. $367 \mathrm{p}$.

6. Cunfer, G. 2005. On the Great Plains: agriculture and environment. College Station, TX, USA: Texas A\&M University Press. 292 p.

7. SAndoz, M. 1935. Old Jules. Boston, MA, USA: Little, Brown. $424 \mathrm{p}$.

8. DAvIs, J. W. 2010. Wyoming range war: the infamous invasion of Johnson County. Norman, OK, USA: University of Oklahoma Press. 383 p.

9. Osgood, E. S. 1929. The day of the cattleman. Minneapolis, MN, USA: University of Minnesota Press. 283 p.

10. Wentworth, E. N. 1948. America's sheep trails: history, personalities. Ames, IA, USA: Iowa State College Press. 667 p.

11. Gilfillan, A. B. 1929. Sheep: life on the South Dakota range. Boston, MA, USA: Little, Brown. 272 p.

12. DALE, E. E. 1930. The range cattle industry: ranching on the Great Plains from 1865 to 1925 . Norman, OK, USA: University of Oklahoma Press. 216 p.

\section{Additional Reading}

Atherton, L. 1961. The cattle kings. Bloomington, IN, USA: Indiana University Press. 308 p.

Jordan, T. G. 1993. North American cattle ranching frontiers, origins, diffusion, and differentiation. Albuquerque, NM, USA: University of New Mexico Press. 439 p.

Roosevelt, T. 1899. Ranch life and the hunting trail. New York, NY, USA: Century. 186 p.

Starrs, P. F. 1998. Let the cowboy ride, cattle ranching in the American West. Baltimore, MD, USA: Johns Hopkins University Press. 356 p.

Author is Professor of History, North Dakota State University, Fargo, ND 58105, USA, isern@plainsfolk.com. 